\title{
SALIVARY GLAND TUMORS IN A BRAZILIAN POPULATION: A RETROSPECTIVE STUDY OF 124 CASES
}

\author{
Pablo Agustin Vargas, Renê Gerhard, Vergílius J. F. Araújo Filho and Inês Vieira \\ de Castro
}

VARGAS PA et al. - Salivary gland tumors in a Brazilian population: a retrospective study of 124 cases. Rev. Hosp. Clín.

Fac. Med. S. Paulo 57(6):271-276, 2002.

Salivary gland tumors constitute a highly heterogeneous histopathologic group. There are few epidemiological studies of large series of benign and malignant salivary gland tumors in Brazil.

MATERIAL AND METHODS: Hospital records of 124 patients with salivary gland tumors diagnosed from January 1993 to December 1999 were reviewed. The patients were analyzed according to gender, age, size, location, and histopathology of the tumor.

RESULTS AND CONCLUSIONS: Patients with benign and malignant tumors presented with a mean age of 47.7 and 48.8 years, respectively. The frequency of benign tumors was $80 \%(\mathrm{n}=99)$ and malignant tumors $20 \%(\mathrm{n}=25)$. Tumors were localized in the parotid gland $71 \%(\mathrm{n}=88)$, in the submandibular gland $24 \%(\mathrm{n}=30)$, and in the minor salivary glands $5 \%$ $(\mathrm{n}=6)$. The most common benign tumors were pleomorphic adenoma in $84 \%(\mathrm{n}=84)$ and Warthin's tumor in $13 \%(\mathrm{n}=13)$. Among malignant tumors, mucoepidermoid carcinoma was the most common in $52 \%(\mathrm{n}=13)$, adenoid cystic carcinoma occurred in $20 \%(\mathrm{n}=5)$, and carcinoma ex pleomorphic adenoma was detected in $12 \%(\mathrm{n}=3)$.

DESCRIPTORS: Salivary gland tumors. Brazilian epidemiology.

\section{INTRODUCTION}

Salivary gland tumors are uncommon, corresponding to approximately $3 \%$ to $10 \%$ of neoplasms of the head and neck region ${ }^{1,2}$. Incidence rates of malignant salivary gland tumors range from 0.5 to 1.2 cases per 100,000 inhabitants per year ${ }^{3,4}$. These tumors occur mainly in the parotid gland, but the submandibular gland, minor salivary gland (15\% of all salivary gland neoplasms), and sublingual gland can be affected too ${ }^{1}$. There are few epidemiological studies of large series of benign and malignant salivary gland tumors in Brazil. The goal of this study was to retrospectively analyze 99 benign and 25 malignant primary epithelial tumors of the major and minor salivary glands, regarding age, gender, tumor location, tumor size, and histological type of these lesions in Brazilian patients.

\section{MATERIAL AND METHODS}

The data were collected from 1993 to 1999 from the files of our division. We found during this period 124

From the Division of Oral Pathology, Faculty of Odontology of PiracicabaUNICAMP and Department of Pathology and Head and Neck Surgery, Hospital das Clínicas, Faculty of Medicine, University of São Paulo. tumors of the salivary glands, 99 being benign and 25 malignant. Information about age, gender, tumor location, and tumor size was obtained from each clinical record. The histopathological analysis of all cases was meticulously reviewed and classified according to the Armed Forces Institute of Pathology $^{5}$ (AFIP) by 3 expert pathologists.

\section{RESULTS}

Patients with benign and malignant tumors presented with a mean age of 47.7 and 48.8 years, respectively. The distributions of age, gender, tumor location, size, and histopathological diagnosis are shown in tables 1, 2, 3, 4, 
and 5. No case of salivary gland tumor was noted in the sublingual gland.

\section{BENIGN TUMORS}

\section{Pleomorphic Adenoma}

Eighty-four tumors were diagnosed as pleomorphic adenoma (PA), which corresponded to $59 \%$ of all tumors of our sample. The parotid gland was affected in 58 cases, followed by 24 and 2 cases in submandibular and minor salivary glands, respectively. The fe- male-to-male ratio was $2: 1$. The age range was $13-84$ years. The mean age for both groups (female and male) was 39 years of age. The average size (maximum diameter) was $3.12 \mathrm{~cm}$ (range $0.5-10 \mathrm{~cm}$ ). Seven out of $84 \mathrm{PA}$ recurred.

\section{Warthin's Tumor}

Thirteen patients in our study (10.5\%) had Warthin's tumor. Warthin's tumors affected only the parotid gland, and were bilateral in 1 case. This tumor occurred in 10 males and 3 fe- males. The age range was 43-73 years. The mean age for both groups (female and male) was 59 years of age. The average size (maximum diameter) was $4.15 \mathrm{~cm}$ (range, $1.5-7.5 \mathrm{~cm}$ ).

\section{Basal Cell Adenoma}

One basal cell adenoma case was diagnosed in the parotid gland of a man of 44 years of age. This tumor was $2.20 \mathrm{~cm}$ at the maximum diameter.

\section{Myoepithelioma}

One myoepithelioma was detected

Table 1 - Age and gender of patients with 99 benign and 25 malignant primary epithelial salivary gland tumors.

\begin{tabular}{|c|c|c|c|c|}
\hline \multirow[t]{2}{*}{ Tumors } & \multicolumn{2}{|c|}{ Gender } & \multirow[t]{2}{*}{ Age (years) } & \multirow[t]{2}{*}{ Age range (years) } \\
\hline & Male & Female & & \\
\hline \multicolumn{5}{|l|}{ Benign } \\
\hline Pleomorphic adenoma & $29(34.52 \%)$ & $55(65.48 \%)$ & 39.00 & $13-84$ \\
\hline Warthin's tumor & $10(76.92 \%)$ & $3(23.08 \%)$ & 59.00 & $43-73$ \\
\hline Basal cell adenoma & $1(100.00 \%)$ & 0 & 44.00 & \\
\hline Myoepithelioma & 0 & $1(100.00 \%)$ & 49.00 & --_-_- \\
\hline \multicolumn{5}{|l|}{ Malignant } \\
\hline Mucoepidermoid carcinoma & $5(38.46 \%)$ & $8(61.54 \%)$ & 37.92 & $17-76$ \\
\hline Adenoid cystic carcinoma & $2(40.00 \%)$ & $3(60.00 \%)$ & 55.20 & $35-77$ \\
\hline Carcinoma ex pleomorphic adenoma & 0 & $3(100.00 \%)$ & 51.00 & $30-73$ \\
\hline Acinic cell carcinoma & $1(100.00 \%)$ & 0 & 36.00 & ----- \\
\hline Adenocarcinoma NOS & 0 & $1(100.00 \%)$ & 48.00 & ----- \\
\hline Epithelial-myoepithelial carcinoma & $1(100.00 \%)$ & 0 & 73.00 & --_--_ \\
\hline Papillary cystadenocarcinoma & $1(100.00 \%)$ & 0 & 41.00 & --_--- \\
\hline
\end{tabular}

Table 2 - Location of 99 benign salivary gland tumors.

\begin{tabular}{|c|c|c|c|c|c|c|c|}
\hline & \multicolumn{2}{|c|}{ Parotid gland } & \multicolumn{2}{|c|}{ Submandibular gland } & \multicolumn{2}{|c|}{ Minor salivary gland } & \multirow[t]{2}{*}{ Total $n$} \\
\hline & $\mathrm{n}$ & $\%$ & $\mathrm{n}$ & $\%$ & $\mathrm{n}$ & $\%$ & \\
\hline Pleomorphic adenoma & 58 & 69.05 & 24 & 28.57 & 2 & 2.38 & 84 \\
\hline Warthin's tumor & 13 & 100 & 0 & 0.00 & 0 & 0.00 & 13 \\
\hline Basal cell adenoma & 1 & 100 & 0 & 0.00 & 0 & 0.00 & 1 \\
\hline Myoepithelioma & 1 & 100 & 0 & 0.00 & 0 & 0.00 & 1 \\
\hline Total & 73 & 73.73 & 24 & 24.24 & 2 & 2.02 & 99 \\
\hline
\end{tabular}

Table 3 - Location of 25 malignant salivary gland tumors.

\begin{tabular}{|c|c|c|c|c|c|c|c|}
\hline & \multicolumn{2}{|c|}{ Parotid gland } & \multicolumn{2}{|c|}{ Submandibular gland } & \multicolumn{2}{|c|}{ Minor salivary gland } & \multirow[t]{2}{*}{ Total $\mathrm{n}$} \\
\hline & $\mathrm{n}$ & $\%$ & $\mathrm{n}$ & $\%$ & $\mathrm{n}$ & $\%$ & \\
\hline Mucoepidermoid carcinoma & 9 & 69.2 & 1 & 7.69 & 3 & 23.0 & 13 \\
\hline Adenoid cystic carcinoma & 0 & 0.00 & 4 & 80.0 & 1 & 20.0 & 5 \\
\hline Carcinoma ex pleomorphic adenoma & 3 & 100 & 0 & 0.00 & 0 & 0.00 & 3 \\
\hline Acinic cell carcinoma & 1 & 100 & 0 & 0.00 & 0 & 0.00 & 1 \\
\hline Adenocarcinoma NOS & 0 & 0.00 & 1 & 100 & 0 & 0.00 & 1 \\
\hline Epithelial-myoepithelial carcinoma & 1 & 100 & 0 & 0.00 & 0 & 0.00 & 1 \\
\hline Papillary cystadenocarcinoma & 1 & 100 & 0 & 0.00 & 0 & 0.00 & 1 \\
\hline Total & 15 & 60.0 & 6 & 24.0 & 4 & 16.0 & 25 \\
\hline
\end{tabular}


Table 4 - Size of benign and malignant tumors of salivary gland.

\begin{tabular}{lcc}
\hline Tumors & Average size $(\mathrm{cm})$ & $\begin{array}{c}\text { Minimum and } \\
\text { Maximum diameter }(\mathrm{cm})\end{array}$ \\
\hline Benign & 3.12 & $0.5-10$ \\
Pleomorphic adenoma & 4.15 & $1.5-7.5$ \\
Warthin's tumor & 2.20 & ----- \\
Basal cell adenoma & 2.00 & ----- \\
Myoepithelioma & 3.06 & $1.0-6.0$ \\
Malignant & 4.10 & $3.0-5.8$ \\
Mucoepidermoid carcinoma & 3.50 & $1.5-4.5$ \\
Adenoid cystic carcinoma & 2.00 & ----- \\
Carcinoma ex pleomorphic adenoma & 1.20 & ----- \\
Acinic cell carcinoma & 6.00 & ----- \\
Adenocarcinoma NOS & 4.50 & ----- \\
Epithelial-myoepithelial carcinoma & & \\
Papillary cystadenocarcinoma &
\end{tabular}

Table 5 - Histopathological diagnosis of 99 benign and 25 malignant salivary gland tumors.

\begin{tabular}{lcc}
\hline Histological type & $\mathrm{n}$ & \% for group \\
\hline Benign & & \\
$\quad$ Pleomorphic adenoma & 84 & 84.84 \\
$\quad$ Warthin's tumor & 13 & 13.13 \\
$\quad$ Basal cell adenoma & 1 & 1.01 \\
$\quad$ Myoepithelioma & & 1.01 \\
Malignant & 13 & 52.00 \\
$\quad$ Mucoepidermoid carcinoma & 5 & 20.00 \\
Adenoid cystic carcinoma & 3 & 12.00 \\
Carcinoma ex pleomorphic adenoma & 1 & 4.00 \\
Acinic cell carcinoma & 1 & 4.00 \\
Adenocarcinoma NOS & 1 & 4.00 \\
Epithelial-myoepithelial carcinoma & 1 & 4.00 \\
Papillary cystadenocarcinoma & & \\
\hline
\end{tabular}

in the parotid gland of a woman of 49 years of age. This tumor was a $2.00 \mathrm{~cm}$ at the maximum diameter.

\section{MALIGNANT TUMORS}

\section{Mucoepidermoid Carcinoma}

Thirteen tumors were detected as mucoepidermoid carcinoma, and these accounted for $10.5 \%$ of all cases or $52 \%$ of the malignant tumors. We noted 9,3 , and 1 case in the parotid, minor salivary, and submandibular glands, respectively. Seven cases were histologically classified as low grade (5 cases located in the parotid gland and 2 cases in the minor salivary

\section{Adenoid Cystic Carcinoma}

Five tumors were histopathologically diagnosed as adenoid cystic carcinoma (ACC), and these accounted for
$4 \%$ of all cases or $20 \%$ of the malignant tumors. We observed 4 cases of ACC in the submandibular gland and 1 in the minor salivary gland. The predominant histological subtype of ACC was cribriform (3 cases located in the submandibular gland) followed by a solid variant (1 case located in the submandibular gland and another in the minor salivary gland). ACC affected 3 females and 2 males. The age range was 35-77 years. The mean age for both groups (female and male) was 55.2 years. The average size (maximum diameter) was $4.10 \mathrm{~cm}$ (range, $3.0-5.8 \mathrm{~cm})$.

\section{Carcinoma ex Pleomorphic Ad- enoma}

Three cases were diagnosed as carcinoma ex pleomorphic adenoma (CPA) and these accounted for $2.4 \%$ of all tumors or $12 \%$ of the malignant salivary gland tumors. We detected 3 cases of CPA only in the parotid gland. The malignant component noted in all cases was adenocarcinoma. CPA affected only women in our study population. The age range was 30-73 years. The peak incidence was in the $5^{\text {th }}$ decade. The average size (maximum diameter) was $3.50 \mathrm{~cm}$ (range, $1.5-4.5 \mathrm{~cm}$ ).

\section{Acinic Cell Carcinoma}

One acinic cell carcinoma case was diagnosed in the parotid gland of a man of 36 years of age. This tumor had a maximum diameter of $2.00 \mathrm{~cm}$.

\section{Adenocarcinoma not otherwise speci- fied (NOS) low grade}

One adenocarcinoma NOS case was observed in the submandibular gland of a woman of 48 years of age. This tumor had a maximum diameter of $1.20 \mathrm{~cm}$.

\section{Epithelial-Myoepithelial \\ Carcinoma}

One epithelial-myoepithelial carcinoma was identified in the parotid 
gland of a man of 73 years of age. This tumor had a maximum diameter of $6.00 \mathrm{~cm}$.

\section{Papillary Cystadenocarcinoma}

One papillary cystadenocarcinoma was noted in the parotid gland of a man of 41 years of age. This tumor had a maximum diameter of $4.50 \mathrm{~cm}$.

\section{DISCUSSION}

In this present study, we reviewed 124 major and minor salivary gland tumors, revealing a predominance of benign (80\%) compared to malignant tumors $(20 \%)$. The vast majority of our salivary gland tumors occurred in a major salivary gland (95\%), especially in the parotid gland. We found a higher prevalence of salivary gland tumors in females $(60 \%)$ than in males $(40 \%)$. The peak incidence was in the $4^{\text {th }}$ decade. In contrast, Frade Gonzalez et al. ${ }^{4}$ observed a predominance of salivary gland tumors in the male group $(58.75 \%)$ and in the $7^{\text {th }}$ decade of age.

We found in the English literature a predominance of benign salivary gland tumors (60\% to $80 \%$ ) compared with malignant tumors (20\% to $40 \%$ ), which is similar to our findings. Satko et al. ${ }^{6}$, analyzing a group of 1021 Slovakian patients with salivary gland tumors, observed that the frequency of benign tumors (74\%) was higher than that of malignant tumors (26\%). Ma'aita et al. ${ }^{7}$ analyzing 221 salivary gland tumors in a Jordanian population, found 151 benign and 70 malignant tumors. Osuch-Wojcikiewicz et al. ${ }^{8}$, studying 332 Polish patients with salivary gland tumors, reported 275 benign and 57 malignant tumors. In contrast, Bardwill et al. ${ }^{9}$ and Lopes et al. ${ }^{10}$ reported a higher prevalence of malignant tumors in minor salivary glands. However, as these data were collected from cancer centers ${ }^{9,10}$, a certain degree of bias must be considered.
In our opinion, it is more appropriated to consider the prevalence of benign and malignant tumors of minor salivary glands as similar. We detected in our sample $16.9 \%$ major and $3.22 \%$ minor salivary gland tumors that were malignant; however, when we considered only tumors occurring in the minor salivary glands, malignant tumors were more prevalent, representing 4 out of 6 or $66.6 \%$ of tumors.

No case of salivary gland tumor was noted in the sublingual gland in our study. This result demonstrates the low prevalence of sublingual tumors, as has been reported by Eveson et al. ${ }^{1}$, who observed 1 sublingual tumor to 100 parotid tumors. Similarly, Ma'aita et al. ${ }^{7}$ reported 1 sublingual tumor $(0.4 \%)$ among 221 cases. In contrast, Satko et al. ${ }^{6}$ reported sublingual tumors in 33 out of 1021 salivary gland tumors, which presented a higher incidence (3.2\%) than that of minor salivary gland tumors (3\%).

Pleomorphic adenoma was the most common tumor $(67.7 \%)$ of all salivary glands in the present study and corresponded to $84.8 \%$ of all benign tumors. Eighty-two cases occurred in major glands (58 cases in the parotid and 24 in the submandibular gland) compared with 2 cases in minor salivary glands. All epidemiological papers analyzing the prevalence of salivary gland tumors in the head and neck region showed a singular predominance of pleomorphic adenoma (50\% to $80 \%$ ) among benign and malignant tumors ${ }^{4,6,8}$. The parotid gland is the main site affected by pleomorphic adenomas followed by the submandibular and minor salivary glands.

Warthin's tumor (WT) comprised $13 \%$ of the benign salivary gland tumors, but none were found in the submandibular, sublingual, or minor salivary glands. The frequency observed in the literature of WT ranged from 9\% to 28\% $\%^{5,11-13}$. Most bilateral parotid gland tumors are WT, but bilateralism occurred in only 1 out of 13 cases in our study population.

Basal cell adenomas and myoepitheliomas occurred only in the parotid gland. Basal cell adenomas are reported as clinical cases affecting principally the parotid gland, and the peak incidence has ranged from the $4^{\text {th }}$ to the $7^{\text {th }}$ decade ${ }^{14}$. Myoepithelioma represents about $1 \%$ to $1.5 \%$ of all salivary gland tumors and is most frequently located in the parotid gland, as we found in our study.

Mucoepidermoid carcinomas (MEC) were more common in major salivary glands $(8 \%$ of salivary gland tumors) than in minor salivary glands $(2.4 \%)$. When we evaluated only malignant tumors, MEC was the most common tumor (52\%). We detected 7 low-grade cases, 2 intermediate-grade cases, and 4 high-grade cases of malignancy. Of the 234 cases of MEC reported by Goode et al. ${ }^{15}, 178$ cases were low grade, 18 cases intermediate grade, and 31 cases high grade of malignancy.

Adenoid cystic carcinoma (ACC) occurred in 5 cases of the total sample, 4 cases $(16 \%$ of malignant salivary gland tumors) in the submandibular gland, and 1 case in a minor salivary gland (4\%). Szmeja et al. ${ }^{16}$, studying 111 cases of ACC, observed that the main site affected was the parotid gland (47 cases), and the most common location of ACC in a minor salivary gland was the palate (14 cases).

Carcinoma ex pleomorphic adenoma formed $12 \%$ of malignant salivary gland tumors and affected only the parotid gland in our study population. Olsen et al. ${ }^{17}$ reported 73 cases of carcinoma ex pleomorphic adenoma, of which $64 \%$ occurred in males and $36 \%$ in females. The mean age was 61 years. Adenocarcinoma (31 cases) and salivary duct carcinoma (24 cases) were the most common malignant subtypes. Our 3 cases affected females only, the peak incidence was the $5^{\text {th }}$ 
decade, and the only malignant histological subtype observed was adenocarcinoma.

Acinic cell carcinoma, adenocarcinoma NOS, epithelial-myoepithelial carcinoma, and papillary cystadenocarcinoma occurred in 1 case each and affected the major salivary glands.

\section{CONCLUSIONS}

The epidemiological analysis of 124 salivary gland tumors has permitted the following conclusions:
1) Patients with benign and malignant tumors presented with a mean age of 47.7 and 48.8 years, respectively.

2) The frequency of benign tumors was $80 \%(\mathrm{n}=99)$ and of malignant tumors was $20 \%(n=25)$.

3) $71 \%(\mathrm{n}=88)$ of the tumors were localized in the parotid gland, $24 \%$ $(\mathrm{n}=30)$ in the submandibular gland, and $5 \%(\mathrm{n}=6)$ in the minor salivary glands.

4) The most common benign tumors were pleomorphic adenoma (84\%, $\mathrm{n}$ $=84)$ and Warthin's tumor $(13 \%, \mathrm{n}$
= 13). Among malignant tumors, mucoepidermoid carcinoma was the most common $(52 \%, \mathrm{n}=13)$ followed by adenoid cystic carcinoma $(20 \%, \mathrm{n}=5)$, and carcinoma ex pleomorphic adenoma $(12 \%, \mathrm{n}=3)$.

\section{ACKNOWLEDGEMENTS}

The authors thank the paramedical staff (Jairo Marcondes Silva and Douglas Moreira) who provided the slides for histopathological study and $\mathrm{CNPq}$ for the financial support.
VARGAS PA e col. - Estudo retrospectivo de 124 casos de tumores de glândulas salivares em uma população brasileira. Rev. Hosp. Clín. Fac. Med. S. Paulo 57(6):271-276, 2002.

Tumores de glândulas salivares apresentam características histopatológicas altamente heterogêneas. Existem poucos estudos epidemiológicos analisando um número elevado de tumores de glândulas salivares benignos e malignos no Brasil.

MATERIAL E MÉTODOS: Revisamos os prontuários hospitalares de
124 pacientes com tumores de glândulas salivares durante o período de Janeiro de 1993 até Dezembro de 1999. Os pacientes foram analisados de acordo com o sexo, idade, tamanho do tumor, localização e tipo histopatológico.

RESULTADOS E CONCLUSÕES:

Pacientes com tumores benignos e malignos apresentaram uma média de idade de 47,7 e 48,8 anos, respectivamente. A freqüência de ocorrência dos tumores benignos foi de $80 \%(n=99)$ e dos tumores malignos de $20 \%(n=25)$. Tumores foram localizados na parótida em $71 \%(n=88)$ dos casos, na glândula submandibular em 24\% (n=30), e glândulas salivares menores em $5 \%(n=6)$. Os principais tumores benignos foram o Adenoma Pleomórfico que representou $84 \%(n=84)$ dos casos e o Tumor de Warthin com $13 \%(n=13)$ dos casos. Entre os tumores malignos, o Carcinoma Mucoepidermóide foi o mais comum correspondendo a $52 \%$ dos casos $(n=13)$, seguido pelo Carcinoma Adenóide Cístico em 20\% (n=5) e Carcinoma ex Adenoma Pleomórfico que foi detectado em $12 \%$ dos casos $(n=3)$.

DESCRITORES: Tumores de glândulas salivares. Epidemiologia. 
1. EVESON JW \& CAWSON RA - Salivary gland tumors: a review of 2410 cases with particular reference to histological types, site, age, and sex distribution. J Pathol 1985; 146:51-58.

2. AROTIBA GT - Salivary gland neoplasms in Lagos, Nigeria. West Afr J Med 1996; 15:11-17.

3. PACHECO-OJEDA L, DOMEISEN H, NARVAEZ M et al. Malignant salivary gland tumors in Quito, Ecuador. ORL J Otorhinolaryngol Relat Spee 2000; 62:296-302.

4. FRADE GONZALEZ C, LOZANO RAMIREZ A, GARCIA CABALLERO $\mathrm{T}$ et al. - Epidemiological study of salivary gland tumours. Rev Laryngol Otol Rhinol 1999; 120:331-36.

5. ELLIS GL \& AUCLAIR PL - Tumors of the Salivary Glands. In: ELLIS GL \& AUCLAIR PL Armed Forces Institute of Pathology, Philadelphia, WB Saunders, 1995. p. 129-134 (3 ${ }^{\text {th }}$ series, fasc. 17).

6. SATKO I, STANKO P \& LONGAUEROVA I - Salivary gland tumours treated in the stomatological clinics in Bratislava. $\mathbf{J}$ Craniomaxillofac Surg 2000; 28:56-61.

7. MA'AITA JK, AL-KAISI N, AL-TAMIMI $S$ et al. - Salivary gland tumors in Jordan: a retrospective study of 221 patients. Croat Med J 1999; 40:539-42.

8. OSUCH-WOJCIKIEWICZ E, JANCZEWSKI G, DOBRZYNSKI P et al. - Tumors of the parotid glands in the material of the Department of Otolaryngology of the Medical Academy in Warsaw in 1986-1995. Otolaryngol Pol 1999; 53: 431-34.

9. BARDWILL JM, REYNOLDS CT, IBANEZ ML et al. - Report of 100 tumors of minor salivary glands. Am J Surg 1966; 112: 493-7.
10.LOPES MA, KOWALSKI LP, SANTOS GC et al. - A clinicopathologic study of 196 intraoral minor salivary gland tumors. J Oral Pathol Med 1999; 28: 264-67.

11.CHRISTENSEN NR, CHARABI S, SORENSEN WT et al. - Benign neoplasms in the parotid gland in the county of Copenhagen 1986-1995. Ugeskr Laeger 1998; 160:6066-069.

12.CHUNG YF, KHOO ML, HENG MK et al. - Epidemiology of Warthin's tumour of the parotid gland in an Asian population. Br J Surg 1999; 86:661-64.

13.WATANABE T, ICHIMIYA I, SUZUKI M et al. - Clinical study of bilateral tumors. Nippon Jibiinkoka Gakkai Kaiho 1999; 102:1169-174.

14.SUZUKI S, OKAMURA H \& OHTANI I - Bilateral parotid gland basal cell adenomas. Case report. ORL J Otorhinolaryngol Relat Spec 2000; 62:278-81.

15.GOODE RK, AUCLAIR PL \& ELLIS GL - Mucoepidermoid carcinoma of the major salivary glands. Clinical and histopathologic analysis of 234 cases with evaluation of grading criteria. Cancer 1998; 82:1217-224.

16.SZMEJA Z, KULCZYNSKI B, CITOWICKI W et al. - Adenoid cystic carcinomas of the head and neck (cylindromas). Otolaryngol Pol 1999; 53:539-44.

17.OLSEN KD \& LEWIS JE - Carcinoma ex pleomorphic adenoma: a clinicopathologic review. Head Neck 2001; 23:705-12.

Received for publication on February 20, 2002. 